\title{
EFEKTIVITAS INSTRUKSI GESTUR (NON-VERBAL) DENGAN INSTRUKSI VERBAL UNTUK PENGEMBANGAN BERNYANYI PADUAN SUARA
}

\author{
Henry S Pranoto \\ Universitas Pelita Harapan \\ Grace_Jhsp@yahoo.com
}

\begin{abstract}
Abstrak
Kegiatan penelitian paduan suara ini merupakan bagian dari pengembangan masyarakat di bidang musik dari Fakultas Ilmu Seni Universitas Pelita Harapan kepada para murid dan penyanyi baik di dalam lingkungan universitas maupun masyarakat di sekitar wilayah Karawaci dan Jakarta. Salah satu tujuan dari kegiatan ini adalah untuk dapat membantu pengembangan bernyanyi para peserta, baik secara individu ataupun berkelompok (paduan suara). Penelitian ini menggunakan metode kuantitatif deskriptif. Penulis berharap agar penelitian ini dapat membantu para konduktor, anggota paduan suara, para donatur, dan semua orang yang terlibat untuk dapat memperoleh hasil yang maksimal bagi program pengembangan paduan suara yang dilakukan. Terdapat 20 orang penguji $(n=20)$ yang ikut ambil bagian sebagai professional clinicians dalam penelitian ini. Penelitian ini menerapkan metode perhitungan one sample chi square. Para pengamat (clinicians) telah secara acak dipilih sebagai bagian dari Festival Singers of Florida, yang dijadwalkan untuk berkunjung ke Universitas Pelita Harapan (UPH). Para pengamat dalam kegiatan penelitian ini merupakan para musisi dan pelatih yang profesional di bidang paduan suara dan vokal, yang tergabung di dalam grup Festival Singers of Florida di bawah pimpinan Dr. Kevin Fenton, Florida State University, Amerika Serikat.
\end{abstract}

Kata kunci: instruksi gestur; instruksi verbal; paduan suara

\begin{abstract}
This choral clinic research project is part of the community development service program of Faculty of Arts, Pelita Harapan University, for students and singers of UPH, and communities surrounding Karawaci and Jakarta, to help them improve, both individual singing and choral singing technique. It is a quantitative descriptive music research. The researcher hopes that this event will help all participants of the choral clinic (conductors, choir members, choral donors, and all people contribute to the choral music development) gain significant improvement on their choir and optimally manage their sources in developing and planning their choral music program. There are 20 participants $(n=20)$ who will take part in this experimental research, applying the one sample chi square measurement. Those participants are randomly selected from the member of the Festival Singers of Florida who is visiting Pelita Harapan University (UPH). They are all professional observers and clinicians who are organized and being parts of Festival Singers of Florida, under the direction of Dr. Kevin Fenton, Assistant Professor of Choral Conducting, Florida State University, United States of America.
\end{abstract}

Keywords: gesture instructions; verbal instructions; choral

\section{Pendahuluan}

Kegiatan paduan suara di Indonesia berkembang sangat pesat dalam beberapa tahun terakhir ini. Hal ini dikarenakan adanya peningkatan minat bernyanyi dalam masyarakat, sumber daya pengajar, dan kemudahan akses terhadap lagu-lagu paduan suara, baik dari dalam maupun luar negeri. Perkembangan ini membuat minat masyarakat dan penggerak seni paduan suara berlomba-lomba untuk menjadi yang terbaik dalam menyanyikan/ 
memimpin paduan suara yang dilatih. Selain itu, penyelenggaraan festival/ lomba paduan suara, baik yang berskala nasional maupun internasional juga mulai banyak dilaksanakan antara lain Pesta Paduan Suara Gerejawi (PESPARAWI), Bali International Choral, Medan International Choral. Maka Universitas Kristen di Indonesia sangatlah diharapkan untuk dapat berperan aktif dalam membantu meningkatkan kualitas bernyanyi dalam paduan suara, antara lain dengan mengadakan kegiatan pelatihan-pelatihan dan seminarseminar paduan suara yang berkualitas dan berskala internasional. Adanya pelatihan dan seminar paduan suara tersebut dapat membantu peningkatan kualitas berpaduan suara di Indonesia. Oleh karena itu, pendidikan musik diharapkan dapat membantu meningkatkan kualitas penyajian musik (performance) dan tingkat ekspresivitas (expressiveness) bermusik secara individu - individual performer dan kelompok—independent performers (Broomhead, 2001, p. 72), maupun untuk membantu pengembangan kesehatan (wellbeing) dan spiritualitas pribadi ataupun berjemaat (Joseph, 2015, p. 29). Cohen menyatakan bahwa keikutsertaan seseorang dalam kegiatan seni dalam masyarakat (community-based cultural program) dapat memberikan dampak positif dalam meningkatkan dan melakukan upaya pencegahan bagi kesehatan (kesehatan jasmani secara umum, berkurangnya kunjungan cek kesehatan, penggunaan obat, terjatuh, perasaan kesendirian, semangat juang/ morale, dan kemampuan beraktivitas) dalam diri (Cohen et al., 2006, p. 733). Kegiatan paduan suara bahkan dapat memberikan dampak positif bagi manusia yang memiliki kesehatan mental yang kronis dan penderita difabel sehingga mereka dapat memperoleh keuntungan secara sosial (diterima dalam masyarakat) dan juga kesehatan jasmani (Dingle, Brander, Ballantyne, \& Baker, 2013, p. 419).

Kegiatan klinik paduan suara dalam penelitian ini melibatkan praktisi dan para choral conductors dari Amerika Serikat, yang kebanyakan tergabung dalam Festival Singers of Florida. Melalui kegiatan klinik paduan suara ini, kelompok-kelompok paduan suara, konduktor, dan donatur paduan suara dapat melihat pentingnya kegiatan pelatihan dan klinik paduan suara yang dilakukan untuk meningkatkan mutu berpaduan suara. Mereka juga harus mempertimbangkan pemahaman bahasa musik yang dimiliki (verbalinstructional language dan non-verbal-conducting gesture) dalam mengikuti kegiatan pelatihan-pelatihan tersebut. Para pemerhati paduan suara perlu melihat unsur efektivitas dari kedua instructional language tersebut (verbal dan non-verbal) ketika bergabung dan bernyanyi dalam suatu paduan suara. Dengan demikian, para penggemar, peserta, dan juga 
donator paduan suara dapat memaksimalkan penggunaan dana untuk mendukung pengembangan kelompok-kelompok paduan suara mereka.

Bahasa merupakan media komunikasi yang sangat penting dalam proses transfer informasi kepada orang lain dalam suatu proses belajar mengajar. Lawrence Robinson, Jeanne Segal, dan Melinda Smith (2015), yang juga dikutip oleh Veronica Pendleton (Pendleton, 2017, p. 111), mengatakan bahwa komunikasi secara umum adalah suatu cara untuk menyampaikan pesan/ informasi secara jelas dan efektif supaya orang lain dapat memahami pesan tersebut dengan mudah dan benar, termasuk pemahaman dalam hal emosi dan intensitas dalam berkomunikasi. Dengan bahasa sebagai media untuk penekanan intensitas, maka penggunaan bahasa (verbal language) secara tepat guna dan efektif dapat juga digunakan untuk memberikan penekanan atas maksud tertentu (reinforcement) dari instruksi yang diberikan. Dunn menyatakan bahwa "the group receiving teacher reinforcement received higher posttest performance scores ...” (Dunn, 1997, p. 564). Manusia, melalui proses belajar dan mengajar, perlu berkomunikasi untuk mencapai banyak tujuan seperti menyampaikan ataupun mendapatkan informasi, memengaruhi ataupun dipengaruhi, menambah ataupun membagikan pengetahuan, ataupun hanya untuk berkomunikasi sebagaimana layaknya makhluk sosial yang lain (Hays \& Minichiello, 2005, p. 266). Dengan demikian, bahasa sebagai alat komunikasi yang utama merupakan media yang penting untuk digunakan dan dipertimbangkan dalam berkomunikasi (termasuk di bidang musik), terutama penggunaan bahasa pengantar yang dapat dipahami oleh semua pihak.

Para dirigen (conductors) sangatlah perlu untuk dapat secara efektif menyampaikan pengajaran musik dalam skema belajar mengajar yang dilakukan ketika memimpin latihan paduan suara, supaya dapat menghasilkan penyajian musik yang baik (Yarbrough \& Madsen, 1998, p. 469). Selain dari pemahaman instruksi verbal, para pelatih paduan suara juga harus memiliki kemampuan untuk memahami instruksi non-verbal (conducting gesture) dalam pelatihan musik yang dilakukan, sehingga mereka, baik para pelatih maupun para anggota paduan suara dapat mendapatkan meaningful musical experiences yang dapat mereka nikmati dan pahami. Meskipun kemampuan untuk memahami instruksi non-verbal dari setiap orang berbeda-beda, akan tetapi, kemampuan ini harus terus dikembangkan semaksimal mungkin, sehingga, "ketika mereka berpartisipasi dengan nyaman, sukses/ berhasil, dan semandiri mungkin dalam sebuah pengalaman bermusik yang bermakna ..., maka akan terjadi transisi dari apa yang mereka pelajari dalam konteks 
pendidikan atau sekolah kedalam konteks kedewasaan hidup dalam masyarakat dan di rumah tempat mereka tinggal" (Jellison, 2000). Oleh karena itu, penelitian ini memusatkan perhatian kepada efektivitas penggunaan instruksi verbal dan non-verbal dalam pelatihan musik paduan suara agar para pelaku dan penggiat paduan suara dapat mendapat pengalaman bermusik yang bermakna dan optimal dalam hidup mereka. Instruksi verbal menggunakan bahasa Inggris akan digunakan dalam penelitian ini karena bahasa Inggris merupakan bahasa pengantar yang paling banyak digunakan dalam dunia pendidikan, terutama di bidang musik. Hal ini terbukti dengan masih banyaknya buku-buku literatur tentang musik yang ditulis dalam bahasa Inggris dan digunakan sebagai buku pelajaran di banyak sekolah dan universitas di Indonesia.

Banyak penelitian telah dilakukan dengan berfokus pada penggunaan bahasa nonverbal dalam kegiatan-kegiatan paduan suara, seperti contohnya: digunakan untuk melihat tingkat efektivitas dari aspek komunikasi non-verbal dari conducting (Weelden, 2002, p. 165), persepsi conducting gesture baik dalam hal pelatihan dan pertunjukan (Napoles, 2012), maupun untuk melihat tingkat ekspresivitas bermusik yang dapat dihasilkan oleh bahasa non-verbal (conducting gesture) dari seorang dirigen (Morrison, Price, Geiger, \& Cornacchio, 2009). Pelatihan musik yang menitikberatkan pada hal-hal yang berhubungan dengan bahasa verbal sebagai media untuk berkomunikasi secara umum (dalam dunia pendidikan maupun dalam kehidupan sehari-hari) juga telah banyak dilakukan. Dengan demikian, para pengajar-terutama pendidik musik di Indonesia-perlu melakukan tinjauan, bukan hanya bagi para peserta didik, tetapi juga bagi para pendidik dalam kemampuannya untuk memahami instruksi verbal (in English) dan non-verbal (conducting gesture) untuk meningkatkan kemampuan bermusik, terutama dalam bidang paduan suara. Kedua instruksi tersebut (verbal language dan non-verbal/ conducting gesture) dibutuhkan dalam membuat dan menentukan struktur kegiatan pelatihan paduan suara (rehearsal organizational structure). Menurut pendapat Cox, rehearsal orgaizational structure ini sangat menentukan tingkat keberhasilan para pelatih paduan suara dalam memberikan kegiatan pelatihan yang dilakukan (Cox, 1989, p. 215).

\section{Metode Penelitian}

Peneliti menggunakan metode Kuantitatif Deskriptif dalam penulisan ini untuk mendapatkan pernyataan dan perhitungan nyata (real count) berupa angka dalam penelitian Deskriptif untuk menjawab pertanyaan mengenai apa yang terjadi (Weelden, 2016, p. 6), 
yang dapat memberikan/ memaparkan hasil akhir (tanpa melakukan suatu perubahan, penambahan, ataupun perlakuan tertentu pada obyek/ bidang persoalan yang diteliti) secara efektif dan optimal. Pembuktian penelitian menggunakan perhitungan angka tersebut adalah untuk menunjukkan hasil berupa angka (quantitative) berdasarkan data-data yang terkumpul selama proses penelitian dilakukan. Dengan demikian, tujuan dari penelitian Deskriptif ini adalah untuk "memberikan data sesuai dengan prosedur dan keadaan yang sekarang (current condition), membangun hubungan antara faktor-faktor dan kondisi yang terkait, dan memberikan penilaian/ determinasi mengenai suatu kebutuhan ataupun gaya/ kecenderungan terkait (trends) yang sedang berlaku" (Weelden, 2016, p. 6). Pengumpulan data dalam penelitian ini dikumpulkan berdasarkan surveys berupa questionnaires yang dijawab (menggunakan Yes/ No) oleh para profesional observers dari Festival Singers of Florida. Metode perhitungan yang akan digunakan oleh peneliti adalah menggunakan pengukuran One Sample Chi Square Method (nonparametric statistics) untuk mengukur perbandingan tingkat efektivitas dari penggunaan media non-verbal (conducting gesture) dengan verbal Instruction (in English) dalam pengembangan paduan suara melalui kegiatan klinik paduan suara.

\section{Pembahasan}

Terdapat lima paduan suara yang berpartisipasi dalam kegiatan klinik paduan suara ini. Masing-masing paduan suara mendapat waktu 30 menit untuk mendapat pelatihan dalam klinik paduan suara ini. Para pengamat paduan suara yang berjumlah 20 orang akan menjawab lima pertanyaan yang akan diberikan dalam bentuk kertas kuesioner untuk mengukur ada atau tidaknya perubahan signifikan yang terjadi dari pelatihan paduan suara tersebut. Sebelum menilai, para pengamat diberikan instruksi perubahan cara mengajar dari Dr. Kevin Fenton. Kertas kuesioner berisi masing-masing dua pertanyaan, dan satu pertanyaan di akhir sesi klinik diberikan untuk mengukur ada atau tidaknya perubahan yang mencolok dari paduan suara tersebut. Masing-masing paduan suara menyanyikan lagu yang dipilih secara lengkap sebanyak dua kali yakni di awal dan akhir sesi klinik.

Dalam pengamatan yang menggunakan metode One Sample Chi Square ini, para pengamat hanya menjawab "ya" atau "tidak" (mencoret kotak yang telah disediakan). Adapun pertanyaan yang disiapkan peneliti adalah lima pertanyaan mengenai ada atau tidaknya perubahan/ peningkatan mutu yang signifikan setelah melakukan kegiatan mengajar verbal dan non-verbal. Para pengamat yang berjumah 20 orang akan menjawab 
lima pertanyaan untuk masing-masing paduan suara yang dilatih/ ditampilkan. Semua pengamat akan melakukan observasi dengan posisi duduk membelakangi paduan suara (tidak melihat paduan suara) dan mereka hanya akan melihat penampilan paserta (melihat paduan suara) pada saat paduan suara tersebut menyajikan kembali lagu yang mereka bawakan pada kali yang terakhir. Hal ini dilakukan peneliti untuk mengurangi pengaruh visualisasi (audio-visual) dari penampilan paduan suara, seperti yang sudah dipaparkan oleh Finnãs bahwa "live presentation seemed to affect experiences on the 'lively to quiet' continuum for lively..." (Finnäs, 2001, p. 71). Setelah semua pertanyaan tersebut dikelompokkan, probabilitas kategori jawaban adalah sebanyak enam kategori.

Proses pengambilan data dilakukan dengan menggunakan dua jenis arahan yang dilakukan oleh pemimpin dari pengamat professional yaitu Dr. Kevin Fenton. Petunjuk/ arahan dalam klinik paduan suara ini adalah berupa arahan menggunakan bahasa Inggris (verbal) dan arahan menggunakan penekanan pada bahasa tubuh (gestur/ instruksi nonverbal). Semua 20 orang $(n=20)$ pengamat profesional paduan suara yang terlibat merupakan penyanyi dari Festival Singers of Florida, Amerika Serikat yang menggunakan bahasa Inggris. Pengarahan menggunakan bahasa pengantar bahasa Inggris (tanpa gerakan tubuh) ditandai oleh Dr. Kevin Fenton dengan acungan dua jari (menunjukkan angka dua) kepada pengamat sebelum memberikan instruksinya kepada paduan suara. Proses pemberian petunjuk pada pengarahan yang menggunakan bahasa Inggris (verbal instruction) adalah sebagai berikut:

1. Peserta paduan suara dipersilahkan untuk menyanyi lagu dalam bahasa Inggris dan dinilai oleh 20 orang pengamat paduan suara profesional yang merupakan bagian dari Festival Singers of Florida, tanpa melihat paduan suara tersebut (facing back from the choir).

2. Setelah memberikan tanda arahan (angka dua) bagi 20 orang pengamat, Dr. Kevin Fenton memberikan arahan pada bagian-bagian lagu yang perlu mendapat perbaikan. Instruksi ini dilakukan tanpa penerjemah bahasa. Pengamat profesional juga dilarang menggunakan gerakan tubuh (body languages/gestur) dalam memberikan arahan.

3. Dirigen memimpin paduan suara dalam menyanyikan lagu tersebut dengan harapan terdapat perubahan/ perkembangan yang sesuai dengan instruksi.

4. Seluruh pengamat profesional (20 orang) kembali melakukan penilaian kepada kualitas paduan suara tersebut, terutama pada bagian yang diinstruksikan tanpa melihat secara langsung pada paduan suara. 
Dr. Kevin Fenton melakukan pengarahan dalam bahasa Inggris dengan penambahan penekanan pada bahasa tubuh (gestur) dengan penandaan acungan jari telunjuk (menunjukkan angka satu). Kode ini ditunjukkan kepada pengamat profesional sebelum memberikan instruksi kepada paduan suara. Proses dari pemberian petunjuk yang menggunakan bahasa tubuh (non-verbal instruction) adalah sebagai berikut:

1. Peserta paduan suara dipersilahkan untuk menyanyi lagu dalam bahasa Inggris dan dinilai oleh pengamat profesional (20 orang) sebagai bagian dari Festival Singers of Florida, tanpa melihat paduan suara tersebut.

2. Setelah memberikan tanda arahan (angka satu) bagi 20 orang pengamat, Dr Kebin Fenton memberikan arahan pada bagian-bagian lagu yang perlu mendapat perbaikan. Instruksi ini dilakukan tanpa terjemahan dan menekankan pada penggunaan gerakan tubuh (gestur).

3. Dirigen kemudian memimpin paduan suara dalam menyanyikan lagu tersebut dengan harapan diperoleh perubahan yang sesuai dengan arahan yang telah diberikan.

4. Seluruh pengamat profesional (20 orang) kembali melakukan penilaian kepada kualitas paduan suara tersebut, terutama pada bagian yang diinstruksikan untuk menilai ada atau tidaknya perbaikan/ perubahan signifikan yang terjadi, tanpa melihat paduan suara tersebut.

Proses pelatihan dan pemberian instruksi dalam kegiatan klinik paduan suara ini memberikan hasil sebanyak 500 jawaban yang dikumpulkan dari semua pengamat profesional Festival Singers of Florida, Amerika Serikat. Peneliti mengelompokkan dan menyusun semua data tersebut ke dalam enam buah kriteria jawaban (verbal significant, verbal no significant, non-verbal significant, non-verbal no significant, significant improvement result, dan no significant improvement result). Nilai pengamatan diambil dari total hasil penilaian yang telah dilakukan oleh semua pengamat profesional yakni nilai $(n)$ sebesar 500. Total nilai $n$ ini digunakan untuk mendapatkan nilai yang diharapkan $(E)$. Nilai $E$ diambil dari pembagian nilai $n$ terhadap enam jenis kriteria penilai. Dengan demikian, nilai $E$ yang dihasilkan adalah 83.33. Salah satu persyaratan dalam menggunakan metode Chi Square adalah bahwa nilai E haruslah lebih besar dari 5. Oleh karena nilai E dari hasil penelitian ini adalah sebesar 83.33, maka perhitungan penelitian dapat dilanjutkan pada tahap perhitungan selanjutnya. Penulis menggunakan rumus perhitungan Chi Square sebagai berikut:

$$
X^{2}=\frac{(O-E)^{2}}{E}
$$


Henry S Pranoto: Efektivitas Instruksi Gestur (Non-Verbal) Dengan Instruksi Verbal Untuk Pengembangan Bernyanyi Paduan Suara

Kesimpulan dari total perhitungan untuk semua kategori jawaban beserta nilai yang diharapkan, termasuk juga nilai $n$ dan $E$ dapat dilihat secara terperinci pada tabel 1 .

Tabel 1. Total perhitungan semua kategori jawaban beserta nilai O/E yang diharapkan

\begin{tabular}{cccccccc}
\hline & $\begin{array}{c}\text { Verbal- } \\
\text { Significant }\end{array}$ & $\begin{array}{c}\text { Verbal-No } \\
\text { Significant }\end{array}$ & $\begin{array}{c}\text { Non } \\
\text { Verbal- } \\
\text { Significant }\end{array}$ & $\begin{array}{c}\text { Non } \\
\text { Verbal-No } \\
\text { Significant }\end{array}$ & $\begin{array}{c}\text { Significant } \\
\text { Improvement } \\
\text { Result }\end{array}$ & $\begin{array}{c}\text { No Significant } \\
\text { Improvement } \\
\text { Result }\end{array}$ & \\
\hline Observed & 180 & 42 & 164 & 14 & 94 & 6 & $\begin{array}{c}n= \\
500\end{array}$ \\
Expected & 83.33 & 83.33 & 83.33 & 83.33 & 83.33 & 83.33 & $\begin{array}{c}\mathrm{E}= \\
500 / 6\end{array}$ \\
\hline
\end{tabular}

*Sumber: Pranoto (2019)

Penggunaan rumus perhitungan Chi Square tersebut, peneliti mendapatkan rangkaian nilai jawaban pada kesimpulan hasil untuk kategori jawaban verbal significant= 112.15 , verbal no significant $=20.50$, non-verbal significant $=78.10$, non-verbal no significant $=57.68$, significant improvement result $=1.37$, dan no significant improvement result= 71.76. Dari hasil perhitungan Chi Square, angka jawaban 112.15 menunjukkan bahwa verbal instruction cukup efektif untuk digunakan dalam pelatihan paduan suara yang dilakukan; sedangkan angka jawaban 78.10 menunjukkan bahwa non-verbal instruction juga cukup efektif untuk dapat digunakan dalam pelatihan paduan suara pada penelitian yang dilakukan. Selain itu, hasil tersebut juga menunjukkan angka jawaban 20.50 yang menyatakan bahwa verbal instruction kurang dapat menunjukkan perubahan yang signifikan dalam pelatihan ini dan angka jawaban 57.68 menyatakan bahwa nonverbal instruction juga kurang menunjukkan perubahan yang signifikan dalam pelatihan paduan suara yang dilakukan. Dari semua hasil perhitungan, peneliti masih belum melihat perbedaan dari kedua angka jawaban tersebut (verbal significant dan non-verbal significant) untuk dapat menyimpulkan perbandingan tingkat efektivitas yang terjadi secara ilmiah.

Peneliti menindaklanjuti perhitungan yang didapat dengan menghitung nilai total dari Chi Square $\left(X^{2}\right)$ dengan cara melakukan penjumlahan total dari semua nilai $C h i$ Square pada setiap kategori jawaban, sehingga nilai yang diperoleh adalah 341.56. Peneliti akan menggunakan acuan nilai degree of freedom 5 yang mengacu kepada enam kategori jawaban pada penelitian dikurangi dengan satu (6 dikurangi 1). Peneliti menerapkan nilai kritis (Critical value) sebesar 0.05, yang juga dikenal dengan sebutan nilai alfa $(\alpha)$. Nilai alfa ini menjelaskan bahwa dari total 100 kali penelitian, kemungkinan terjadinya kesalahan hasil penelitian adalah sebesar 5 kali kesalahan, sehingga hal ini seringkali 
dikenal dengan sebutan nilai kritis (critical value). Nilai koresponden dari nilai kritis dan degree of freedom secara umum dapat dilihat pada table international Chi Square Critical Value Table. Apabila dihubungkan nilai alfa $=.05$ dengan $d f=5$, maka nilai Chi Square yang didapatkan adalah sebesar 11.07.

Karena total nilai perhitungan Chi Square $\left(X^{2}\right)=341.56$ lebih tinggi dibandingkan dengan koresponden nilai yang tertera pada Chi Square Critical Value Table (11.07), maka peneliti menolak hipotesa awal $\left(H_{0}\right)$ yang menyatakan bahwa tidak ada perbedaan yang signifikan antara gestur dan instruksi verbal. Dengan kata lain, hasil penelitian Chi Square tersebut mengindikasikan bahwa ada perbedaan yang signifikan dari efektivitas non-verbal (conducting gesture) dengan instruksi verbal (in English) dalam proses pengembangan bernyanyi pada paduan suara selama mengikuti kegiatan klinik paduan suara. Peneliti harus melanjutkan pada tahap perhitungan yang selanjutnya, untuk dapat mengitung besarnya nilai perbedaan (the effect size - Phi) tersebut, dengan menggunakan rumus perhitungan $P h i(\Phi)$ :

$$
\Phi=\sqrt{\frac{x^{2}}{N}}
$$

Dengan menggunakan rumus perhitungan di atas, peneliti mendapatkan nilai Phi (Ф) sebesar 0.83. Peneliti akan melanjutkan perhitungan nilai post hoc tests untuk menghitung perbandingan nilai perbedaan yang paling signifikan dari setiap kategori jawaban (enam kemungkinan kategori). Dari kemungkinan perbandingan yang ada diperoleh sebanyak 15 pasang perbandingan, yakni verbal significant Vs. verbal no significant, verbal significant Vs. non-verbal significant, verbal significant Vs. non-verbal no significant, verbal significant Vs. significant improvement result, verbal significant Vs. no significant improvement result, verbal no significant Vs. non-verbal significant, verbal no significant Vs. non-verbal no significant, verbal no significant Vs. significant improvement result, verbal no significant Vs. no significant improvement result, nonverbal significant Vs. non-verbal no significant, non-verbal significant Vs. significant improvement result, non-verbal significant Vs. no significant improvement result, nonverbal no significant Vs. significant improvement result, non-verbal no significant Vs. no significant improvement result, significant improvement result Vs. no significant improvement result. Pembandingan pada setiap kategori perlu dilakukan sehingga peneliti dapat melihat/ menemukan terjadinya perbedaan perbandingan angka yang cukup signifikan untuk setiap kategori. 
Dalam melakukan perhitungan pada tahapan berikutnya dan melihat perbedaan dari setiap perbandingannya, peneliti harus menentukan nilai alfa yang baru sehingga dapat memperoleh hasil yang lebih akurat untuk perhitungan yang lebih lanjut. Peneliti menerapkan perhitungan modified Bonferroni Correction untuk mendapatkan nilai degree of freedom yang baru. Dari perbandingan dua kategori jawaban yang dilakukan, peneliti menggunakan rumus di atas dan mendapatkan nilai total degree of freedom $\left(\sum \mathrm{df}\right)$ sebesar $=$ $(2-1)$ x $15=15$ dan nilai Modified Bonferroni Correction sebesar 0.36 sebagai berikut:

Nilai Modified Bonferroni Correction $=\frac{1-(1-a)}{c}^{\sum d f}=\frac{1-(1-.05)}{15}^{15}=0.36$.

Peneliti mendapatkan nilai alfa yang baru sebesar 0.36 yang akan digunakan pada tahap perhitungan selanjutnya (post hoc tests). Untuk dapat melihat analisa data yang lebih tepat, peneliti menerapkan perhitungan binomial test, sehingga nilainya harus dipindahkan ke perhitungan data nilai z ( $z$ score). Rumus yang digunakan untuk perhitungan $z$ score adalah sebagai berikut:

$$
z=\frac{(x+0.5)-N P}{\sqrt{N P Q}}
$$

Dalam perhitungan $z$ score ini, nilai $P$ dan nilai $Q$ adalah nilai proposisi yang diharapkan dari setiap kategori jawaban. Hipotesa awal $\left(H_{0}\right)$ menunjukkan bahwa secara teoritis, setengah (50\%) dari setiap kategori jawaban adalah berbanding sama dengan jumlah jawaban yang diharapkan. Dengan demikian, nilai harapan dalam perbandingan untuk setiap kategori jawaban masing-masing adalah 50\%, sehingga nilai yang dibandingkan di setiap kategori (nilai $P$ dan nilai $Q$ ) adalah masing-masing sebesar 0.5. Nilai $x$ adalah nilai terkecil dari kedua kategori yang dibandingkan. Nilai $N$ adalah total nilai dari kedua kategori yang dibandingkan. Dengan demikian, perhitungan Z untuk setiap kategori jawaban adalah sebagai berikut:

Tabel 2. Perhitungan nilai z semua kategori perbandingan menggunakan $\mathrm{p}$-value baru

\begin{tabular}{clcc}
\hline No. & \multicolumn{1}{c}{ Kategori Jawaban } & Nilai Z & $\mathrm{p}$-value \\
\hline 1. & Verbal significant Vs. verbal no significant & -9.19 & $<0.00006$ \\
2. & Verbal significant Vs. non-verbal significant & -0.81 & 0.42 \\
3. & Verbal significant Vs. non-verbal no significant & -11.85 & $<0.00006$ \\
4. & Verbal significant Vs. significant improvement result & -5.13 & $<0.00006$ \\
5. & Verbal significant Vs. no significant improvement result & -12.68 & $<0.00006$ \\
6. & Verbal no significant Vs. non-verbal significant & -8.43 & $<0.00006$ \\
7. & Verbal no significant Vs. non-verbal no significant & -3.61 & $<0.00006$ \\
\hline
\end{tabular}




\begin{tabular}{clcc}
\hline No. & \multicolumn{1}{c}{ Kategori Jawaban } & Nilai Z & p - value \\
\hline 8. & Verbal no significant Vs. significant improvement result & -4.37 & $<0.00006$ \\
9. & Verbal no significant Vs. no significant improvement result & -5.06 & $<0.00006$ \\
10. & Non-verbal significant Vs. non-verbal no significant & -11.17 & $<0.00006$ \\
11. & Non-verbal significant Vs. significant improvement result & -4.30 & $<0.00006$ \\
12. & Non-verbal significant Vs. no significant improvement result & -12.04 & $<0.00006$ \\
13. & Non-verbal no significant Vs. significant improvement result & -7.60 & $<0.00006$ \\
14. & Non-verbal no significant Vs. no significant improvement result & -1.56 & 0.12 \\
15. & Significant improvement result Vs. no significant improvement result & -8.70 & $<0.00006$ \\
\hline
\end{tabular}

*Sumber: Pranoto (2019)

Dalam proses penelitian ini, peneliti menggunakan one tailed test. Untuk mendapatkan nilai $z$ score penuh, maka nilai $p$-value harus dikalikan dua seperti yang tertera pada tabel 2. Dengan nilai kritis (critical value) yang baru 0.36 , maka hampir semua perbandingan kategori jawaban terdapat perbedaan yang signifikan, kecuali pada perbandingan kategori verbal significant Vs. non-verbal significant. Pada perhitungan ketegori jawaban nomor 2 (verbal significant Vs. non-verbal significant) pada tabel 2, peneliti melihat hasil dan nilai perbedaan jawaban yang dihasilkan (nilai jawaban instruksi verbal lebih tinggi dari nilai jawaban instruksi non-verbal). Akan tetapi, nilai z score pada akhir perhitungan menyatakan bahwa nilai perbedaan tersebut masih belum cukup signifikan untuk dapat menentukan satu dari kedua instruksi tersebut (verbal in English dan non-verbal/ conducting gesture) yang paling efektif/ signifikan untuk dapat digunakan dalam kegiatan pelatihan paduan suara.

\section{Kesimpulan}

Hasil yang didapatkan dalam penelitian ini bahwa adanya perbedaan yang signifikan yakni $X^{2}(11.07)=341.56, p<0.05, \Phi=0.83$. Selanjutnya peneliti menindaklanjutinya dengan menerapkan rangkaian perhitungan binomial tests yang menggunakan perhitungan Modified Bonferroni Correction. Hal ini dilakukan untuk dapat melihat pasangan kategori yang memiliki perbedaan signifikan, sehingga kesimpulan yang dihasilkan yaitu terdapatnya perbedaan yang signifikan mengenai tingkat efektivitas.

Selain hasil tersebut, peneliti tidak menemukan adanya perbedaan signifikan lainnya, sehingga penerapan instruksi verbal dan non-verbal dalam mengikuti pelatihan paduan suara, dapat dinyatakan bahwa keduanya menunjukkan peningkatan hasil yang positif dalam pengembangan pelatihan paduan suara yang dilakukan. Akan tetapi, 
penilaian keefektivitasan antara instruksi verbal dengan non-verbal masih belum dapat menunjukkan nilai perbandingan yang cukup signifikan. Sehingga peneliti masih belum dapat menentukan perbedaan tingkat keefektivitasan dari kedua hal tersebut (verbal in English dan non-verbal/ conducting gesture) untuk dapat digunakan dalam kegiatan pengembangan paduan suara.

Saran yang diberikan adalah agar penelitian berikutnya dapat melibatkan lebih banyak paduan suara (lebih dari 5 paduan suara), mengeksplorasi posisi para professional obeservers menjadi menghadap/ melihat paduan suara yang dilatih, menambah durasi pelatihan paduan suara, dan menentukan lagu yang sama untuk dinyanyikan oleh semua paduan suara yang mengikuti kegiatan pelatihan, sehingga dapat melihat perbedaan pada tingkat keefektivitasan antara instruksi verbal dan non-verbal dalam kegiatan penelitian dan pelatihan paduan suara yang dilakukan.

\section{Kepustakaan}

Broomhead, P. (2001). Individual Expressive Performance: Its Relationship to Ensemble Achievement, Technical Achievement, and Musical Background. Journal of Research in Music Education, 49(1), 71-84. Retrieved from http://doi.org/10.2307/3345811

Cohen, G. D., Perlstein, S., Chapline, J., Kelly, J., Firth, K. M., \& Simmens, S. (2006). The Impact of Profesionally Conducted Cultural Programs on the Physical Health, Mental Health, and Social Functioning of Older Adults. The Gerontologist, 46(6), 726-734. Retrieved from http://doi.org/10.1093/geront/46.6.726

Cox, J. (1989). Rehearsal Organizational Structures Used by Successful High School Choral Directors. Journal of Research in Music Education, 37(3), 201-218. Retrieved from http://doi.org/10.2307/3344670

Dingle, G. A., Brander, C., Ballantyne, J., \& Baker, F. A. (2013). "To be heard": The social and mental health benefits of choir singing for disadvantaged adults. Psychology of Music, 41(4), 405-421. Retrieved from http://doi.org/10.1177/0305735611430081

Dunn, D. E. (1997). Effect of Rehearsal Hierarchy and Reinforcement on Attention, Achievement, and Attitude of Selected Choirs. Journal of Research in Music Education, 45(4), 547-567. Retrieved from http://doi.org/10.2307/3345422

Finnäs, L. (2001). Presenting music live, audio-visually or aurally - does it affect listeners' experiences differently? British Journal of Music Education, 18(1), 55-78. Retrieved from http://doi.org/10.1017/S0265051701000146

Hays, T., \& Minichiello, V. (2005). The contribution of music to quality of life in older people: an Australian qualitative study. Ageing \& Society, 25(2), 261-278. Retrieved from http://doi.org/10.1017/S0144686X04002946 
Jellison, J. A. (2000). How Can All People Continue to Be Involved in Meaningful Music Participation? In C. K. Madsen (Ed.), Vision 2020: the Housewright Symposium on the Future of Music Education (pp. 111-137). Reston, VA: MENC.

Joseph, D. Y. (2015). Spiritual connection made through music making: Sharing faith and music in an Australian setting. International Journal of Social, Political, and Community Agendas in the Arts, 10(2), 29-42.

Morrison, S. J., Price, H. E., Geiger, C. G., \& Cornacchio, R. A. (2009). The Effect of Conductor Expressivity on Ensemble Performance Evaluation. Journal of Research in Music Education, 57(1), 37-49. Retrieved from http://doi.org/10.1177/0022429409332679

Napoles, J. (2012). The influences of presentation modes and conducting gestures on the perceptions of expressive choral performance of high school musicians attending a summer choral camp. International Journal of Music Education, 31(3), 321-330. Retrieved from http://doi.org/10.1177/0255761411434823

Pendleton, V. (2017). Long-Term English Language Learners' Experiences Through An Assets Lens: A Phenomenological Study (University of La Verne, California, USA). Retrieved from https://search.proquest.com/openview/b4785d75a2ca4abbcab28a4f773c9923/1 ?pqorigsite $=$ gscholar \&cbl $=18750 \&$ diss $=y$

Weelden, K. V. (2002). Relationships between Perceptions of Conducting Effectiveness and Ensemble Performance. Journal of Research in Music Education, 50(2), 165176. Retrieved from http://doi.org/10.2307/3345820

Weelden, K. V. (2016). Descriptive Research in Music: A Guide to Help Musicians Research What is. Retrieved from http://blackboard.fsu.edu

Yarbrough, C., \& Madsen, K. (1998). The Evaluation of Teaching in Choral Rehearsals. Journal of Research in Music Education, 46(4), 469-481. Retrieved from http://doi.org/10.2307/3345344 